\title{
Actividad peroxidasa y concentración de proteínas en Phaseolus vulgaris l. tratado
} con preparaciones homeopáticas

\author{
Atividade de peroxidase e concentração de proteína em Phaseolus vulgaris $l$. tratado com \\ preparações homeopáticas \\ Actividad peroxidasa y concentración de proteínas en Phaseolus vulgaris $l$. tratado con \\ preparaciones homeopáticas
}

Received: 07/20/2021 | Reviewed: 07/25/2021 | Accept: 07/27/2021 | Published: 08/02/2021

Tarita Cira Deboni

ORCID: https://orcid.org/0000-0001-9243-5877

Federal University of Southern Border, Brasil

E-mail: tarita.deboni@uffs.edu.br

Denise Cargnelutti

ORCID: https://orcid.org/0000-0002-7307-1024

Federal University of Southern Border, Brasil

E-mail: denise.cargnelutti@uffs.edu.br

Júlia Carolina Ghizzoni

ORCID: https://orcid.org/0000-0001-9070-3604

Federal University of Southern Border, Brasil

E-mail: jullycarolina7@gmail.com

Gabriela de Melo Santiago

ORCID: https://orcid.org/0000-0003-4153-5661

Federal University of Southern Border, Brasil

E-mail: gabriela2_melo3@hotmail.com

Egabrieli Garbin

ORCID: https://orcid.org/ 0000-0002-9992-0653

Federal University of Southern Border, Brasil

E-mail: egabrieligarbin123@gmail.com

Alexandre Copatti Loregian

ORCID: https://orcid.org/0000-0003-2877-9629

Regional Integrated University of Upper Uruguai and Missions, Brasil

E-mail: alexandrecloregian@gmail.com

Alexandre Giesel

ORCID: https://orcid.org/0000-0002-9569-015X

Federal University of Technology - Paraná, Brasil

E-mail: alexandergiesel@gmail.com

Pedro Boff

ORCID: https://orcid.org/0000-0002-9041-5503 Santa Catarina Agricultural Research and Rural Extension Company Lages, Brasil E-mail: boff.pedro@yahoo.com.br

Cláudia Petry

ORCID: https://orcid.org/ 0000-0002-4187-1449

Passo Fundo University Foundation, Brasil

E-mail: petry@upf.br

\begin{abstract}
The objective of this work was to evaluate peroxidase activity and protein concentration in the defence system expression of common bean Phaseolus vulgaris L., submitted to different potencies of homeopathic preparations. The treatments were composed by: Arsenicum album, Staphisagria, Silicea and Sulphur, in the 6, 12 and $18 \mathrm{CH}$ potencies, compared to the controls. The bean seeds were sown in pots which were kept in a greenhouse and the treatments were applied to them at $1 \%$ in distilled water since the sowing day, with intervals of 15 days until the R7 stage. The first evaluation was performed at 15 e 60 days after sowing, after artificial mechanical damage. Protein concentration and the activity of guaiacol peroxidase (POD) and ascorbate peroxidase (APX) enzymes were determined. Differences between treatments and controls were estimated by Glass Delta effect size analysis. Staphisagria $12 \mathrm{CH}$ induced greater increase in protein concentration on bean leaves. The Induction on APX and POD activities were observed in leaves treated with Sulphur in all tested potencies. The Glass Delta effect showed undulatory behaviour, sometimes acting positively, sometimes negatively, throughout all evaluations. Homeopathic preparations have the potential to induce biochemical defence mechanisms in beans, acting as resistance elicitors.
\end{abstract}


Keywords: Enzymes; High dynamized dilutions; Homeopathy; Agroecology.

\begin{abstract}
Resumo
O objetivo deste trabalho foi avaliar a atividade da peroxidase e a concentração de proteínas na expressão do sistema de defesa de Phaseolus vulgaris L., submetido a diferentes preparações homeopáticas. Os tratamentos foram compostos por: Arsenicum album, Staphisagria, Silicea e Sulphur, nas potências 6, 12 e $18 \mathrm{CH}$, comparados aos controles. As sementes foram semeadas em vasos mantidos em casa de vegetação. Os tratamentos foram aplicados a $1 \%$ em água destilada a partir da semeadura, com intervalos de 15 dias até o estádio R7. A primeira avaliação foi realizada 15 e 60 dias após a semeadura, após danos mecânicos artificiais. A concentração de proteínas, atividade das enzimas guaiacol peroxidase (POD) e ascorbato peroxidase (APX) foram determinadas. As diferenças entre os tratamentos e os controles foram estimadas pela análise do tamanho do efeito Glass Delta. Staphisagria $12 \mathrm{CH}$ induziu maior aumento na concentração de proteína nas folhas do feijoeiro. As atividades de indução de APX e POD foram observadas em folhas tratadas com Sulphur em todas as potências testadas. O efeito Glass Delta apresentou comportamento oscilatório, em todas as avaliações. As preparações homeopáticas têm potencial para induzir mecanismos de defesa bioquímica em Phaseolus vulgaris L., atuando como eliciadores de resistência.
\end{abstract}

Palavras-chave: Enzimas; Altas diluições dinamizadas; Homeopatia; Agroecologia.

\title{
Resumen
}

El objetivo de este trabajo fue evaluar la actividad peroxidasa y la concentración de proteínas en la expresión del sistema de defensa de Phaseolus vulgaris L., sometido a diferentes preparaciones homeopáticas. Los tratamientos consistieron en: Arsenicum album, Staphisagria, Silicea y Sulphur, en las potencias 6, 12 y $18 \mathrm{CH}$, en comparación con los controles. Las semillas se sembraron en macetas mantenidas en invernadero. Los tratamientos se aplicaron al $1 \%$ en agua destilada de la siembra, con intervalos de 15 días hasta la etapa R7. La primera evaluación se realizó a los 15 y 60 días después de la siembra, luego de un daño mecánico artificial. Se determinó la concentración de proteínas, la actividad de las enzimas guayacol peroxidasa (POD) y ascorbato peroxidasa (APX). Las diferencias entre tratamientos y controles se estimaron analizando el tamaño del efecto Glass Delta. Staphisagria $12 \mathrm{CH}$ indujo un mayor aumento en la concentración de proteínas en las hojas de frijol. Se observaron actividades de inducción de APX y POD en hojas tratadas con azufre en todas las potencias probadas. El efecto Glass Delta mostró un comportamiento oscilatorio en todas las evaluaciones. Las preparaciones homeopáticas tienen el potencial de inducir mecanismos de defensa bioquímicos en Phaseolus vulgaris L., actuando como inductores de resistencia.

Palabras clave: Enzimas; Altas diluciones optimizadas; Homeopatía; Agroecología.

\section{Introduction}

The homeopathy, science and healing art proposed by Hahnemann in the XVIII century, was developed on the basis of healing by the like, Similia Similibus Curentur, the pathogenetic experimentation in the healthy individual, minimal medicine doses and single medicine use (Andrade and Casali 2011; Teixeira 2011). Homeopathic preparations have infinitesimal dilutions with concomitant succussions, and thus promote the individual restoration through the dynamic energy rebalancing and by natural defenses (Carneiro et al. 2011).

Several groups of researchers in Brazil and worldwide have been working on the homeopathy effects and on the outcomes of highly diluted aqueous substances in plants (Santos and Pontes 2013; Teixeira and Carneiro 2017; Ücker et al. 2018). In general, the surveys are grouped into three categories: a) healthy plant models, aiming to investigate questions related to homeopathic potencies and pathogenetic assays; b) phytopathological models, which apply homeopathy in the management of plant diseases and pests, without use restriction in the systems mentioned in the Organics Law, in Brazil; and c) models using plants subjected to abiotic stresses (mineral toxicity, salinity, pH, etc.) (Betti et al. 2009; Majewsky et al. 2009; Jäger et al. 2011, 2015).

The use of homeopathic preparations in plants can improve their internal processes and optimize their development, as well as directly affect the plant physiological pathways with no toxic effects (de Almeida et al., 2021). Homeopathic preparations can also act as resistance inductors to insects and pests, assisting in maintaining plant productivity through the secondary metabolites production (Moreno 2017).

The absence of specific homeopathic medical material for plant species, with a pathogenetic description of the medicines, which already exists in the medical and veterinary areas, makes impracticable the choice of homeopathic remedies 
for plants by classical methods. In this way, selection for plant models is difficult (Carneiro et al. 2011). Therefore, the analogy with existing medical materials is one of the ways to select the medicine to be applied in homeopathy to plants (Toledo et al. 2011).

Considering that homeopathic preparations can cure by reactive side effect of the diseased organism; it is assumed that physiological responses in plants may confer some similarity to those observed in humans (Hahnemann 2001). This would be a verifiable level of similarity in the choice of medicines based on the symptomatic similarity between what is described in human medical materials to the symptoms elected in the plants, also enabling the study of the resistance induction responses of each homeopathic preparation (Bonato 2007).

Research has shown the homeopathy influence on plant secondary metabolism, as observed with the homeopathic medicines Sulphur and Arsenicum album, which improved the production of an essential oil in Mentha arvensis L. (Bonato et al. 2009). In the phytochemical study of Justicia pectoralis Jacq., it was evaluated the production of coumarin (1-2 benzopyrone) using Arnica montana homeopathy. The dynamizatons of Arnica montana caused changes in the plant coumarin content with the use of $3 \mathrm{CH}$ (hahnemannian centesimal dilution order) and $30 \mathrm{CH}$, increasing progressively from $60 \mathrm{CH}$, reaching a maximum of $100 \mathrm{CH}$, followed by a reduction with the use of $200 \mathrm{CH}$ (Andrade et al. 2012). These studies prove the effect of homeopathic treatments on plant metabolism and morphology, and the results vary not only with the species studied, but also with the dynamization or potency of the applied treatment.

Positive results in resistance induction to plant pathogens of common bean cv. carioca were obtained with the homeopathic preparations of Corymbia citriodora, Calcarea carbonica, Silicea and Sulphur, in the 12, 24, 30 and $60 \mathrm{CH}$ dynamizations. All treatments increased the activities of peroxidase, catalase, chitinase, and $\beta-1,3$-glucanase enzymes in at least one of the evaluated potencies in relation to the control, evidencing the inducing potential of the treatments in common bean (Oliveira et al. 2014).

Mioranza et al. (2017) evaluated the effect of the Thuya occidentalis preparation on the nematode Meloidogyne incognita in tomato, as well as they determined plant growth and its defense responses. Eight treatments were tested: 6, 12, 24, 50, 100, 200 and 400CH of Thuya occidentalis, compared with the water control. The activity of plant defense enzymes was increased for peroxidase $(24,50,200$ and $400 \mathrm{CH})$, polyphenoloxidase $(200 \mathrm{CH})$ and phenylalanine ammonia-lyase $(24$ and 50CH) (Mioranza et al. 2017).

It can be noticed that there is still diversity regarding to the experimental model used by the authors and in relation to the evaluated parameters, since it is not clear which chemical compounds are associated with the induced responses and how homeopathy can interfere on them.

The objective of this work was to evaluate protein content and peroxidase activity in the expression of the defense system of common bean Phaseolus vulgaris L. submitted to different potencies of homeopathic preparations.

\section{Methodology}

The experiment was conducted in an acclimatized greenhouse during the 2017/2018 crop and the biochemical analysis were performed at the Entomology and Biochemistry Laboratory of the Universidade Federal da Fronteira Sul, Campus Erechim, RS. The black bean (P. vulgaris) seeds were purchased from family farmers belonging to the city of Paulo Bento, RS, being considered a local accession. The bean plants were cultivated, in the greenhouse, in $3.5 \mathrm{~L}$ polyethylene pots, using as substrate the mixture of latosol soil, organic compost and sand in a 1:1:1 ratio, not sterilized. Three seeds were sown per pot and, after sowing, thinning was performed, leaving only one plant per pot. 


\section{Choice of homeopathic treatments}

Homeopathic medicines were chosen based on the analogy with human medical materials (Tyler 2016) and seeking results that have already been found in plant experimentation (Casali et al. 2009).

The following medications were selected:

- $\quad$ Arsenicum album, indicated as an important medicine for intoxication relieve (Tyler 2016); in plants, it is a germinating stimulant (Casali et al. 2009) and it increased the metabolites content (Bonato et al. 2009).

- $\quad$ Staphisagria, indicated for skin wounds, acute itchy bites (Tyler 2016) and for plants harmed by aphids, mites or nematodes (Casali et al. 2009).

- $\quad$ Silicea terra, indicated for minor skin wounds that heal with difficulty, weak feelings, cold air sensitivity (Tyler 2016) and for plants damaged by herbicide residues, with frequent damage caused by fungi and various growth disruptions (Casali et al. 2009).

- Sulphur, as one of the largest materials used in homeopathy, with broad spectrum of action, for various skin problems (Tyler 2016) and suitable for plants that are easily intoxicated and crops that slowed growth after pesticide use (Casali et al. 2009).

It was decided to use the $6 \mathrm{CH}$ dynamizations, still considered by weight; $12 \mathrm{CH}$, in the limit of the supposed presence of the original active principle; and $18 \mathrm{CH}$, besides the possibility of original particles being present (Bellavite and Betti 2012; Fontes 2017).

Thus, the potencies $6 \mathrm{CH}, 12 \mathrm{CH}$ and $18 \mathrm{CH}$ were chosen, and all the dynamizations of the selected medicines were obtained in homeopathic pharmacy, prepared in 5\% alcohol.

\section{Application of homeopathic treatments}

The treatments Arsenicum album, Staphysagria, Silicea and Sulphur, at $6 \mathrm{CH}, 12 \mathrm{CH}$ and $18 \mathrm{CH}$ dynamizations, were compared to the controls without intervention and with distilled water application. At the application time, the treatments were diluted in $1 \%$ (10 mL for each $1 \mathrm{~L}$ of distilled water) and they were applied directly to the substrate in the pots, using a $200 \mathrm{~L}$ ha-1 spray volume $(40 \mathrm{~mL}$ per pot). The first application was performed at the sowing moment and the others were accomplished fortnightly until the R7 stage (pod formation).

\section{Sample Collection}

Samples were collected at two different times. The first one occurred 15 days after sowing (DAS), in V3 stage, with the first trifoliolate leaf open, when the plants had already received the second application of the treatments on the day before the collection. A whole plant was removed, being separated the root system from the shoot, placed in aluminum bags and immediately immersed in liquid nitrogen for freezing.

In the second collection moment, at 60 DAS, the plants were in R5 stage (pre-flowering). The treatments were applied on the day before and, 10 hours later, mechanical damage was performed, by cutting half of one of the leaflets of each plant. The samples were taken 12 hours after the damage, collecting the damaged trifoliolate leaves, packing them in aluminum bags and immersing them immediately in liquid nitrogen. All samples were kept in an ultra-freezer $(-40 \mathrm{oC})$ until the biochemical analysis moment.

\section{Protein and enzymatic extracts obtainment}

Leaf samples were smashed in liquid nitrogen and homogenized in $3 \mathrm{~mL}$ of $0.05 \mathrm{M}$ sodium phosphate buffer (pH 7.8), 
containing $0.1 \mathrm{mM}$ EDTA (ethylenediamine tetraacetic acid) and 2\% PVP (poly-vinyl-pyrrolidone). The homogenized mixture was centrifuged at 9,500 rpm for 20 minutes at $4{ }^{\circ} \mathrm{C}$, and the supernatant was collected and subsequently used for the evaluations.

\section{Total protein quantification}

For protein quantification, the Bradford method (1976) was used. The protein extract was diluted (1:4) in the extraction buffer. Protein content was evaluated using $50 \mu \mathrm{L}$ of the sample plus $2.5 \mathrm{~mL}$ of Bradford reagent. After five minutes, the reading was taken at $595 \mathrm{~nm}$ in a spectrophotometer. The absorbance values obtained for the samples were compared with a standard curve with known concentrations of bovine serum albumin (BSA). Results obtained for protein levels were expressed as mg protein L-1.

\section{Determination of peroxidase activity}

The activity of guaiacol peroxidase enzyme (POD) was determined according to Zeraik et al. (2008), using guaiacol as a substrate. The quantification of the ascorbate peroxidase enzyme (APX) activity was performed according to Zhu et al. (2004).

\section{Data analysis}

Differences between the treatments and control groups were estimated using effect size analysis. The chosen measure of effect size was the Glass Delta (Glass et al. 1981), due to differences between the standard deviations of the controls in relation to the treatments. Analysis was performed using an effect size calculation tool available online (Ellis 2009). Interpretation of the effect sizes followed the Cohen scale, supplemented by Rosenthal, in which values less than 0.19 are considered "insignificant"; "Small" values between 0.20 and 0.49; "Medium" values between 0.50 and 0.79; "Large" values between 0.80 and 1.29; and "Very large" values greater than 1.30 (Espírito-Santo and Daniel 2015).

$$
\text { Glass's }^{\prime}-\frac{M 1-M 2}{\text { sDcontrol }}
$$

\section{Results and Discussion (can be separated or together) (TNR font 12 - left aligned)}

The protein concentration analysis of the bean's shoot showed that, at least, one potency of Staphisagria, Silicea and Sulphur preparations had great effect, that is, presenting the Glass Delta value higher than 0.80. Only Staphisagria showed a positive value, while the others, had lower effects than the control (Fig. 1, Tab.1). 
Figure 1. Protein concentration (mg L-1) in bean leaves treated with homeopathic preparations (centesimal Hahnemannian $\mathrm{CH})$, compared to the control without intervention (C1) and to the control with distilled water (C2) at 15 days after sowing (A) and at 60 days after sowing, subjected to mechanical stress. Erechim, 2018.

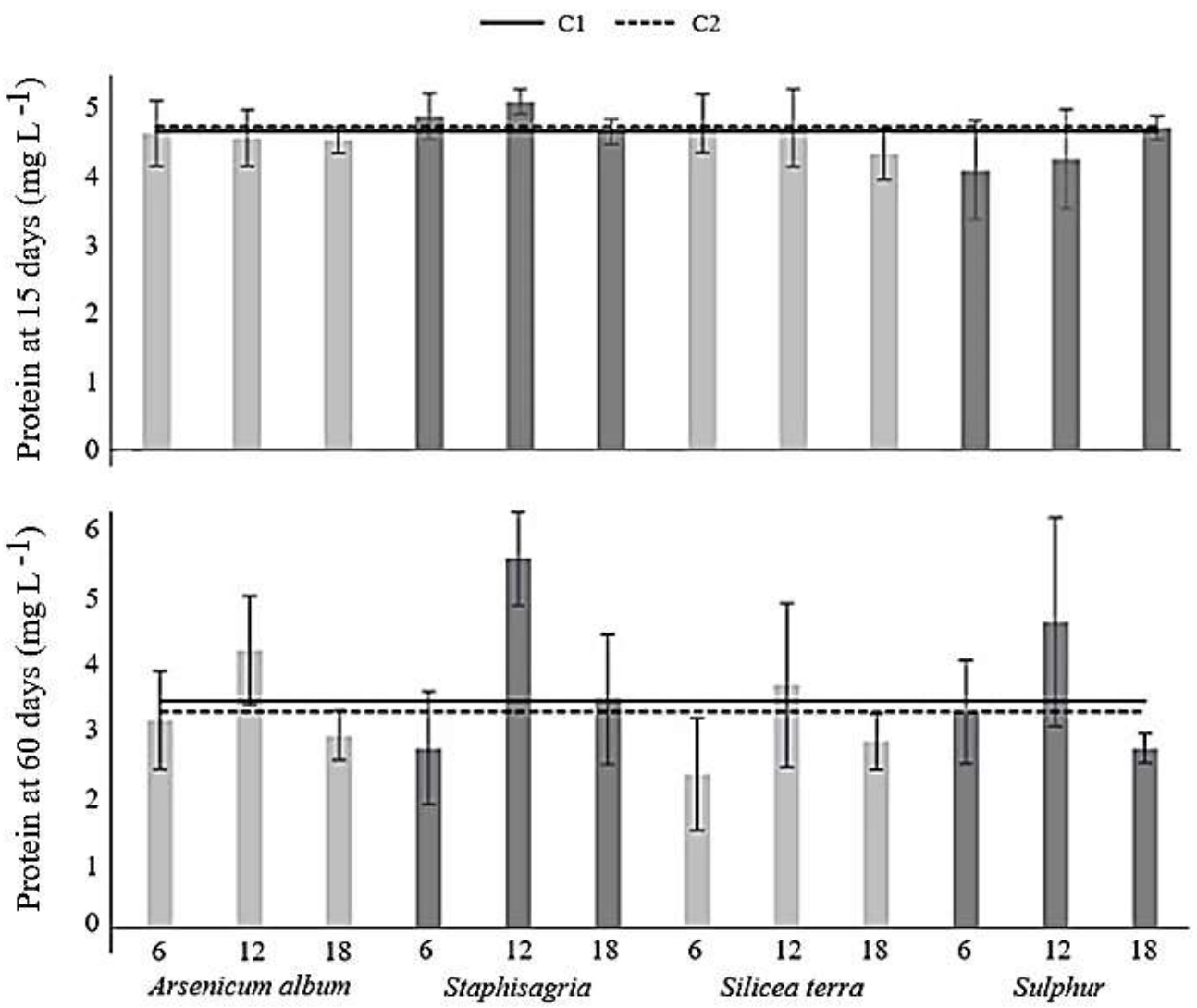

Source: Research collection. 
Research, Society and Development, v. 10, n. 9, e59110918457, 2021

(CC BY 4.0) | ISSN 2525-3409 | DOI: http://dx.doi.org/10.33448/rsd-v10i9.18457

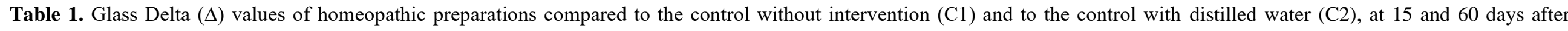
sowing (DAS), after application of analysis. Erechim, RS, Brazil, 2018.

\begin{tabular}{|c|c|c|c|c|c|c|c|c|c|c|c|c|c|c|}
\hline & & & \multicolumn{12}{|c|}{ Homeopathic preparations $\left(\mathrm{CH}^{1}\right)$} \\
\hline \multicolumn{3}{|c|}{ Assessments } & \multicolumn{3}{|c|}{ Arsenicum album } & \multicolumn{3}{|c|}{ Staphisagria } & \multicolumn{3}{|c|}{ Silicea terra } & \multicolumn{3}{|c|}{ Sulphur } \\
\hline & & & $6^{2}$ & 12 & 30 & 6 & 12 & 30 & 6 & 12 & 30 & 6 & 12 & 30 \\
\hline \multirow{4}{*}{$\begin{array}{l}\text { Protein }^{3} \\
\text { (DAS) }\end{array}$} & \multirow{2}{*}{15} & $\Delta \mathrm{Cl}$ & $-0,21$ & $-0,43$ & 0,43 & 0,21 & 1,14 & 0,08 & $-0,25$ & $-0,21$ & $-0,90$ & 0,15 & $-2,07$ & 0,34 \\
\hline & & $\Delta \mathrm{C} 2$ & 0,20 & 0,11 & 0,30 & 0,37 & 0,73 & 0,32 & 0,18 & 0,20 & $-0,06$ & 0,22 & $-0,52$ & 0,42 \\
\hline & \multirow{2}{*}{60} & $\Delta \mathrm{C} 1$ & $-0,47$ & 0,22 & $-0,43$ & $-0,67$ & 1,25 & $-0,06$ & $-0,78$ & $-0,59$ & $-0,59$ & $-0,47$ & $-0,27$ & $-0,47$ \\
\hline & & $\Delta \mathrm{C} 2$ & $-0,12$ & 0,62 & $-0,07$ & $-0,34$ & 1,74 & 0,31 & $-0,45$ & $-0,25$ & $-0,25$ & $-0,12$ & 0,09 & $-0,12$ \\
\hline \multirow{3}{*}{$\begin{array}{l}\mathrm{APX}^{4} \\
(\mathrm{DAS})\end{array}$} & \multirow{2}{*}{15} & $\Delta \mathrm{C} 1$ & 0,58 & 3,00 & 1,21 & 0,49 & 0,74 & 0,67 & $-1,25$ & 0,80 & 1,75 & 1,50 & 0,94 & 2,20 \\
\hline & & $\Delta \mathrm{C} 2$ & $-0,44$ & 0,88 & $-0,09$ & $-0,49$ & $-0,35$ & $-0,39$ & $-1,45$ & $-0,32$ & 0,19 & 0,06 & $-0,24$ & 0,44 \\
\hline & 60 & $\Delta \mathrm{C} 1$ & 0,21 & $-0,18$ & 0,06 & 0,84 & $-0,33$ & 0,05 & 2,10 & 0,45 & 0,36 & 0,44 & 0,55 & 0,39 \\
\hline \multirow{5}{*}{$\mathrm{POD}^{5}$} & \multirow{2}{*}{15} & $\Delta \mathrm{C} 1$ & $-0,85$ & $-2,65$ & $-2,41$ & $-2,44$ & $-1,64$ & $-1,58$ & $-1,30$ & $-2,16$ & $-1,77$ & 2,17 & 0,85 & 1,14 \\
\hline & & $\Delta \mathrm{C} 2$ & 0,48 & $-1,33$ & $-1,33$ & $-1,11$ & $-0,31$ & $-0,25$ & 0,02 & $-0,83$ & $-0,44$ & 3,55 & 2,21 & 2,50 \\
\hline & \multirow[b]{3}{*}{60} & & & & & & \multirow{3}{*}{$\begin{array}{l}-0,67 \\
-0,96\end{array}$} & & & & & & & \\
\hline & & $\Delta \mathrm{C} 1$ & 0,45 & $-0,01$ & 0,16 & 0,07 & & $-0,70$ & $-0,29$ & 0,09 & $-0,42$ & $-0,21$ & $-0,24$ & $-0,48$ \\
\hline & & $\Delta \mathrm{C} 2$ & $-0,16$ & $-0,49$ & $-0,37$ & $-0,43$ & & $-0,99$ & $-0,70$ & $-0,42$ & $-0,79$ & $-0,63$ & $-0,66$ & $-0,83$ \\
\hline
\end{tabular}

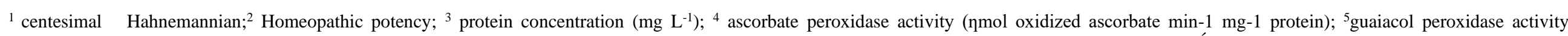

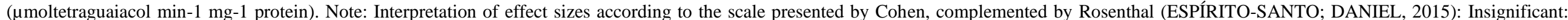
less than 0.19; Small: between 0.20 and 0.49; Medium: between 0.50 and 0.79; Large: between 0.80 and 1.29; Very large: greater than 1.30; Negative values: superior control to treatment.

Source: Research collection. 
Research, Society and Development, v. 10, n. 9, e59110918457, 2021

(CC BY 4.0) | ISSN 2525-3409 | DOI: http://dx.doi.org/10.33448/rsd-v10i9.18457

For both assessment moments, at 15 DAS and 60 DAS, Staphisagria 12CH showed difference in means with the control, corresponding to more than one standard deviation (Fig. 1, Tab.1). This demonstrates a favorable potential of this dynamization in increasing the protein content on bean leaves, increasing $1 \mathrm{mg} \mathrm{L}-1$ compared to the controls (Fig. 1, Tab.1).

It can be noticed that the behaviour of the potencies tested for each preparation was nonlinear, sometimes acting negatively, sometimes acting positively. This pattern is quite clear in Figure 1. Ultra-diluted and succussed preparations are known to have a similar effect to electromagnetic waves, having different dynamics for each potency (Davenas et al. 1988; Bonato and Peres 2007). Thus, it is evident the importance of working with several potencies of the same preparation in homeopathy experimentation, because in single potencies the response information is lost in greater potencies amplitude. In situations where one medicine potency is solely tested, only the negative or even null effect can be found.

According to the trophobiosis theory, the state of dominant protea synthesis, which means the increase in protein contents in relation to the amino acids, can be observed in the present study as a response to pest and disease resistance (Chaboussou 2006). So, when the plant is balanced, it will produce, through its metabolism and photosynthesis, more complex substances, that are hardly digested and assimilated by herbivorous insects, instead of decomposing them into simpler substances. Increasing protein concentration generates more resistant tissues. This entomological resistance is derived from the absence of soluble nutrients and the ease of assimilation (Polito 2006). This fact fully justifies the concept of the Trophobiosis Theory, which postulates that "all vital processes depend on the satisfaction of the living organisms needs, as plants or animals" (Chaboussou 2006).

It is desirable to find homeopathic preparations that stimulate the plant to have dominant proteasynthesis, in the sense that it may cause antixenosis or non-preference reactions in herbivorous insects. Plants may set up a sequence of defense programs that will interfere with the herbivore's food choice (Kant et al. 2015). On the other hand, the fact that some potencies have caused a reduction in leaf protein concentration may be justified by a pathogenesis triggering, that is, the set of signs and symptoms that a healthy organism presents when trying a certain homeopathic medicine (Teixeira 2013).

For homeopathic healing, when a medicine that causes the same pattern of unbalance in healthy plants (pathogenesis) is applied to an unbalanced plant, it would return to its previous balance, restoring its healthy condition (Bonato 2007). The set of pathogenic symptoms frames the Pure Medical Matters (Zoby 2003), which has not been done for vegetables yet due to the reduced number of trials. Because of this, the principle of healing by peers is often overlooked in plants (Bonato 2007; Teixeira and Carneiro 2017).

Therefore, both positive and negative responses can be considered important for the assessment of plant homeopathy. The study of the plant defense system through the evaluation of the activation of biochemical components can introduce more information, not only for crop phytosanitary management, but also bring attributes for pathogenesis studies (Bonato 2007).

The results of ascorbate peroxidase (APX) activity showed that all treatments presented a medium to very large effects, with values between 120 and 180 (nmol oxidized ascorbate min-1 mg-1 protein) in the assessment at 15 days (Fig 2 , Tab 1). The treatments that stood out with the largest effects were Arsenicum album $12 \mathrm{CH}$, Silicea terra $18 \mathrm{CH}$, and Sulphur in two potencies 6 and $18 \mathrm{CH}$. 
Figure 2. Activity of ascorbate peroxide (APX) (nmol oxidized ascorbate min-1 mg-1 protein) in bean leaves treated with homeopathic preparations (centesimal Hahnemannian - CH) of Arsenicum album (Ars.), Silicea terra (Sil.), Staphisagria (Staph.), and Sulphur (Sulph.), compared to the control with no intervention (C1) and to the control with distilled water (C2), at 15 and at 60 days after sowing, subjected to mechanical stress. Erechim, RS, Brazil, 2018.

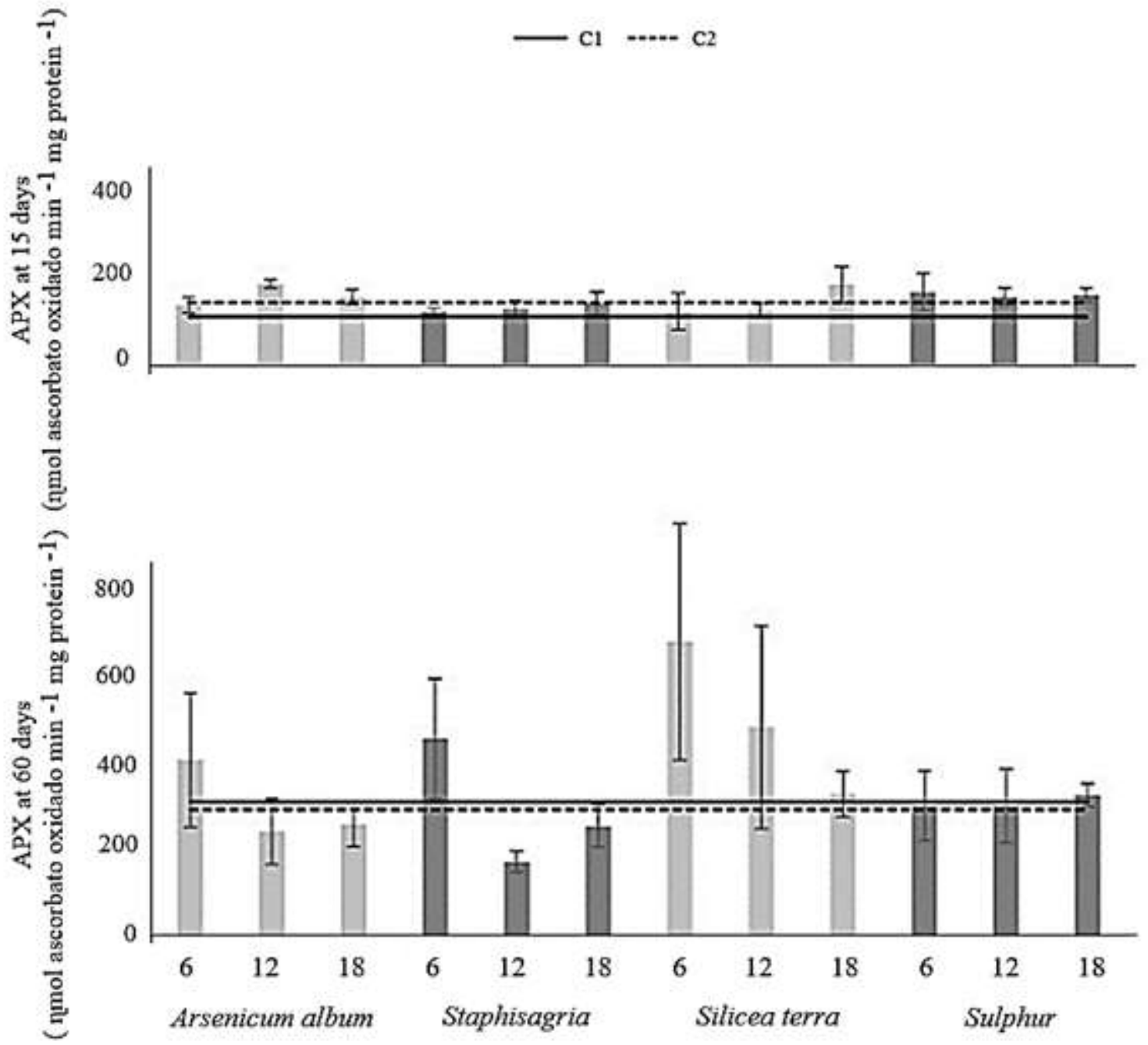

Source: Research collection.

However, this APX behavior was not repeated in the assessment performed at 60 days, after mechanical damage. The only medicine that had a very large effect was Silicea $6 \mathrm{CH}$, showing greater amplitude in the minimum and maximum results (between 150 and 680 nmol oxidized ascorbate min-1 mg-1 protein), followed by Staphisagria $6 \mathrm{CH}$ in this second evaluation. The increase in APX activity of these two treatments was quite pronounced in relation to the others, thus demonstrating the potential of these dynamizations in stimulating plant defense responses after abiotic stress.

Changes in peroxidase activity are correlated with plant defense responses, both caused by biotic and abiotic stresses (Taiz et al. 2017). Increases in this activity are desired and have already been reported in common bean plants using Silicea and Sulphur preparations, at 12, 24, 30 and 60CH dynamizations (Oliveira et al. 2014). The results of the same authors are similar to those observed in the present study with the Silicea preparation, despite being in another dynamization.

It should be considered that a stress, either biotic or abiotic, can be a triggering stimulus for peroxidase activation, 
which can be verified in the noticeable increase in enzyme activity between Figure $2 \mathrm{~A}$ and $2 \mathrm{~B}$. In tomato, increases in peroxidase activity were reported using the preparation of Thuya occidentalis at 6, 12, 24, 50, 100, 200 and $400 \mathrm{CH}$, after biotic stress caused by nematode (Mioranza et al. 2017).

Again, for both evaluations performed (Figure 2A and 2B), we can observe the nonlinear effect of the potencies within each homeopathic preparation tested. This fact can be verified by the negative effect presented in some potencies, in contrast to the positive ones. It is important to point out that experiments with various homeopathic potencies serve to recognize the wave dynamics in homeopathy (Bonato and Peres 2007).

Results of the guaiacol peroxidase (POD) activity at 15 DAS (between 0.1 and $5.4 \mu$ mol tetraguaiacol min-1 mg-1 protein) had a very large effect on practically all treatments tested (Fig 3, Tab 1). However, only the Sulphur preparation showed a positive result, especially using the $12 \mathrm{CH}$ potency, which presented a large increase in the enzyme activity.

Figure 3. Guaiacol peroxidase (POD) activity ( $\mu$ moltetraguaiacol min-1 mg-1 protein) in bean leaves treated with homeopathic preparations (centesimal Hahnemannian - CH) of Arsenicum album (Ars.), Silicea terra (Sil.), Staphisagria (Staph.), and Sulphur (Sulph.), compared to the control with no intervention (C1) and to the control with distilled water (C2), at 15 days after sowing and at 60 days after sowing, subjected to mechanical stress. Erechim, RS, Brazil, 2018.

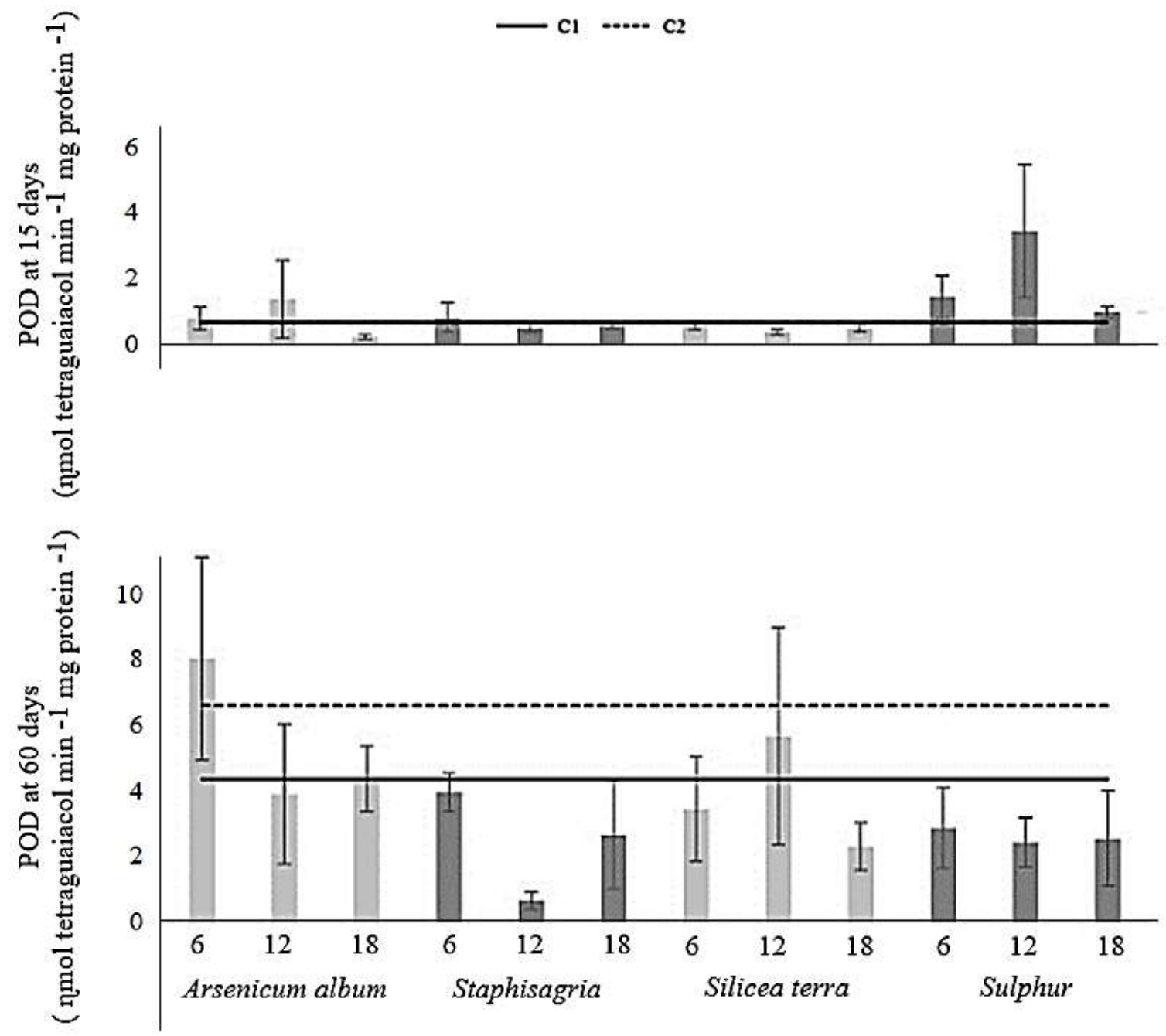

Source: Research collection. 
Research, Society and Development, v. 10, n. 9, e59110918457, 2021

(CC BY 4.0) | ISSN 2525-3409 | DOI: http://dx.doi.org/10.33448/rsd-v10i9.18457

At 60 DAS, after the mechanical damage, it was observed no treatment with a great positive POD effect, in other words, higher than the control, with POD values between 0.6 and 7.4 ( $\mu$ mol tetraguaiacol min-1 mg-1 protein) (Figure 3B). Relevance should be given to the fact that, at this time, there was visible differentiation between the results of the two controls tested (with no intervention and with distilled water), which may have impaired data analysis.

The reduction in POD activity observed at both evaluation times may lead to an $\mathrm{H} 2 \mathrm{O} 2$ accumulation. The accumulation of this metabolite, due to the reduction of POD activity, in turn, could result in APX activity stimulation, observed in Fig 2 Similar result of imbalance between APX and POD relationship was found by Pereira et al. (2010), who evaluated the influence of successive maize selection cycles on the enzymes activity of the antioxidant system. Although the peroxidase enzyme is related to events involving resistance induction, there is no defined pattern for its behavior, which depends on the inducer type, its concentration, time after application in the plant and the stress involved (Bonaldo et al. 2005).

Another important aspect observed in the present study was the positive results using potencies above $12 \mathrm{CH}$. Because homeopathic medicines undergo a serial dilution process that results in extremely low (often unmeasurable) levels of active ingredients, homeopathy generates intense skepticism (Bellavite and Betti 2012). Thus, the greater is the potency or dynamism of the medicine, the less likely we are to find original medicine molecules in the solution (Fontes 2017).

Therefore, potencies above $12 \mathrm{CH}$, as tested here, are challenging and they prove to the scientific community that it is possible to have results even with ultra-dilutions. Most homeopathic studies with healthy plants use one or a few measurement parameters, such as growth, length, weight, area, or germination rate. This limitation can make it difficult to find meaningful results. To intensify the understanding of homeopathic effects on plants, biochemical research plays an important role according to Toledo et al. (2011).

\section{Conclusion}

The homeopathic preparations of Arsenicum album, Silicea terra, Staphisagria, and Sulphur induce non-linear changes in the contents of protein and peroxidase enzymes activity in common bean plants after abiotic stress.

\section{References}

Andrade, F. M. C. D., \& Casali, V. W. D. (2011). Homeopatia, agroecologia e sustentabilidade. Revista Brasileira de Agroecologia, 6(1), 49-56.

Andrade, F. M. C., Casali, V. W. D., \& Cecon, P. R. C. (2012). Efeito de dinamizações de Arnica montana L. no metabolismo de chambá (Justicia pectoralis Jacq.). Revista Brasileira de Plantas Medicinais, 14, 159-162.

Bellavite, P., \& Betti, L. (2012). Homeopathy and the science of high dilutions: when to believe the unbelievable. International Journal of High Dilution Research-ISSN 1982-6206, 11(40), 107-109.

Betti, L., Trebbi, G., Majewsky, V., Scherr, C., Shah-Rossi, D., Jäger, T., \& Baumgartner, S. (2009). Use of homeopathic preparations in phytopathological models and in field trials: a critical review. Homeopathy, 98(04), 244-266.

Bonaldo, S. M., Pascholati, S. F., \& Romeiro, R. D. S. (2005). Indução de resistência: noções básicas e perspectivas. Indução de resistência em plantas a patógenos e insetos, 11-28.

Bonato, C. M. (2007). Homeopathy in vegetal models. International Journal of High Dilution Research-ISSN 1982-6206, 6(21), 24-28.

Bonato, C. M., Proença, G. T. D., \& Reis, B. (2009). Homeopathic drugs Arsenicum album and Sulphur affect the growth and essential oil content in mint (Mentha arvensis L.). Acta Scientiarum. Agronomy, 31(1), 101-105.

Bradford, M. M. (1976). A rapid and sensitive method for the quantitation of microgram quantities of protein utilizing the principle of protein-dye binding. Analytical biochemistry, 72(1-2), 248-254

Casali, V. W. D., Andrade, F. M. C. D., \& Duarte, E. S. M. (2009). Acologia de altas diluições: resultados científicos e experiências sobre uso de preparados homeopáticos em sistemas vivos. In Acologia de altas diluições: resultados científicos e experiências sobre uso de preparados homeopáticos em sistemas vivos (pp. 537-537). 
Research, Society and Development, v. 10, n. 9, e59110918457, 2021

(CC BY 4.0) | ISSN 2525-3409 | DOI: http://dx.doi.org/10.33448/rsd-v10i9.18457

Chaboussou, F. (2006). Plantas doentes pelo uso de agrotóxicos: novas bases de uma prevenção contra doenças e parasitas; a teoria da trofobiose. Expressão Popular.

Davenas, E., Beauvais, F., Amara, J., Oberbaum, M., Robinzon, B., Miadonnai, A., ... \& Benveniste, J. (1988). Human basophil degranulation triggered by very dilute antiserum against IgE. Nature, 333(6176), 816-818.

de Almeida, M. V., Meurer, I. R., \& Manfrini, R. M. (2021). Homeopatia: uma ferramenta agroecológica. Revista Meio Ambiente e Sustentabilidade, 10(20), $102-114$.

Espírito Santo, H., \& Daniel, F. (2017). Calcular E Apresentar Tamanhos Do Efeito EM Trabalhos Científicos (1): As Limitações Do P< 0, 05 Na Análise De Diferenças De Médias De Dois Grupos (Calculating and Reporting Effect Sizes on Scientific Papers (1): P< 0.05 Limitations in the Analysis of Mean Differences of Two Groups). Revista Portuguesa de Investigação Comportamental e Social, 1(1), 3-16.

Fontes, O. L. (2017). Farmácia homeopática: teoria e prática. Editora Manole.

Hahnemann, S. (2001). Organon da arte de curar. In Organon da arte de curar (pp. 248-248).

Jäger, T., Scherr, C., Shah, D., Majewsky, V., Wolf, U., Betti, L., \& Baumgartner, S. (2015). The use of plant-based bioassays in homeopathic basic research. Homeopathy, 104(04), 277-282.

Kant, M. R., Jonckheere, W., Knegt, B., Lemos, F., Liu, J., Schimmel, B. C. J., ... \& Alba, J. M. (2015). Mechanisms and ecological consequences of plant defence induction and suppression in herbivore communities. Annals of botany, 115(7), 1015-1051.

Majewsky, V., Arlt, S., Shah, D., Scherr, C., Jäger, T., Betti, L., ... \& Baumgartner, S. (2009). Use of homeopathic preparations in experimental studies with healthy plants. Homeopathy, 98(04), 228-243.

Mioranza, T. M., Stangarlin, J. R., Müller, M. A., Coltro-Roncato, S., Inagaki, A. M., Meinerz, C. C., ... \& Kuhn, O. J. (2017). Control of Meloidogyne incognita in tomato plants with highly diluted solutions of Thuya occidentalis and their effects on plant growth and defense metabolism. Semina: Ciências Agrárias, 38(4), 2187-2200.

Moreno, N. M. (2017). Agrohomeopatía como alternativa a los agroquímicos. Revista Médica de Homeopatía, 10(1), 9-13.

Oliveira, J. S. B., Maia, A. J. E., Schwan-Estrada, K. A. R. F., Bonato, C. M., Carneiro, S. M. T. P. G., \& Picoli, M. H. S. (2014). Activation of biochemical defense mechanisms in bean plants for homeopathic preparations. African Journal of Agricultural Research, 9(11), 971-981.

Pereira, F. J., Magalhães, P. C., Souza, T. C. D., Castro, E. M. D., \& Alves, J. D. (2010). Atividade do sistema antioxidante e desenvolvimento de aerênquima em raízes de milho'Saracura'. Pesquisa Agropecuária Brasileira, 45, 451-456.

Polito, W. L. (2006). The Trofobiose Theory and organic agriculture: the active mobilization of nutrients and the use of rock powder as a tool for sustainability. Anais da Academia Brasileira de Ciências, 78(4), 765-779.

Santos, G., \& da Silva Pontes, M. (2013). An exploration of the impact factor of Brazilian publications in indexed journals on homeopathy and high dilutions applied in plants. Acta Biomédica Brasiliensia, 4(2), 21-34.

Taiz, L., Zeiger, E., Møller, I. M., \& Murphy, A. (2017). Fisiologia e desenvolvimento vegetal. Artmed Editora.

Teixeira, M. Z. (2011). Evidências científicas da episteme homeopática. Revista de Homeopatia, 74(1/2), 33-56

Teixeira, M. Z. (2013). Similia similibus curentur: the homeopathic healing principle based on modern pharmacology/Similia similibus curentur: o principio de cura homeopatico fundamentado na farmacologia moderna. Revista de Medicina, 92(3), 183-204.

Toledo, M., Stangarlin, J., \& Bonato, C. (2011). Homeopathy for the control of plant pathogens. physiology, $19(20), 21$.

Tyler, M. L. (2016). Retratos de medicamentos homeopáticos com repertório de sintomas. In Retratos de medicamentos homeopáticos com repertório de sintomas (pp. 1150-1150).

Ücker, A., Baumgartner, S., Sokol, A., Huber, R., Doesburg, P., \& Jäger, T. (2018). Systematic review of plant-based homeopathic basic research: an update. Homeopathy, 107(02), 115-129.

Zeraik, A. E., Souza, F. S. A. D., Fatibello-Filho, O., \& Leite, O. D. (2008). Desenvolvimento de um spot test para o monitoramento da atividade da peroxidase em um procedimento de purificação. Química Nova, 31(4), 731-734.

Zhu, Z., Wei, G., Li, J., Qian, Q., \& Yu, J. (2004). Silicon alleviates salt stress and increases antioxidant enzymes activity in leaves of salt-stressed cucumber (Cucumis sativus L.). Plant Science, 167(3), 527-533.

Zoby, E. C. (2003). Matéria Médica Pura de Hartlaub e Trinks: resgatar ou perder?. Cultura homeopatica, 15-20. 